\title{
Headaches among residents within the Selebi Phikwe Nickel-Copper mining environment, Botswana
}

\author{
Georges-Ivo E. Ekosse ${ }^{1 *}$, Linda de Jager ${ }^{2}$ and Dawid J. van den Heever ${ }^{3}$ \\ 1. Mining and Minerals Division, School of Physical and Mineral Sciences, University of Limpopo, \\ South Africa. 2; Faculty of Health and Environmental Sciences, Central University of Technology Free State, \\ P/Bag X20539 Bloemfontein, South Africa. 3; VDH Industrial Hygiene CC.PO. Box 26792 Langenhoven Park, \\ 9330, Bloemfontein, South Africa
}

*Corresponding author: Tel: +27 15268 3492; E-mail: GEkosse@excite.com.

\section{SUMMARY}

Headache occurrences among different classes of residents within a nickel-copper (Ni$\mathrm{Cu}$ ) mining and smelting environment in Botswana are investigated using questionnaires and statistical package for social sciences (SPSS). Interpreted results from respondents indicated that all of the health service providers, $80 \%$ of educational institutions, and 70 $\%$ of businesses enterprises had patients, learners and workers respectively, and $77 \%$ of individuals, complained of one form of headache or the other. Similar high values were obtained when responses were considered according to study sites, especially for frontal and temple headaches. Females suffered slightly more often from headaches than males. Values for sites close to smelter/concentrator plant and mine were in general higher. Mining activities especially the release of sulphur gases and fumes into the atmosphere, and other climatic factors could possibly be contributory to the rampant occurrence of headaches at Selebi Phikwe.

[Afr J Health Sci. 2006; 13:43-52]

\section{Introduction}

The study area, Selebi Phikwe township, is located in the north-eastern part of Botswana, southern Africa, between longitudes $27^{\circ} 47^{\prime} \mathrm{E}$ and $27^{\circ} 53^{\prime} \mathrm{E}$, and latitudes $22^{\circ} 55^{\prime} \mathrm{S}$ and $22^{\circ} 00^{\prime} \mathrm{S}$. The country has a population of 1500000 inhabitants with a $3.1 \%$ growth rate and a density of 2 persons per $\mathrm{km}^{2}$ : Selebi Phikwe is approximately $250 \mathrm{~km}^{2}$ with a population of about 50,000 and a $2.4 \%$ constant growth rate since 1991 [1]. Its population increased from $<5,000$ in 1971 to the present population size characterised by $52.5 \%$ males and $47.5 \%$ female. Rapid population expansion attributed to mining of nickel-copper-cobalt (Ni-Cu-Co) is exerting pressure on existing social, physical and economic infrastructures including the health status of its residents and their surrounding biophysical environment. [2]

Nickel-copper (NI-Cu) mining activities started in 1956, and between 1973 and 1980 opencast mining was carried out, after which underground mining was introduced as a costefficient method. The mining area has four shafts [3] used for transportation of miners, the mined massive sulphides, semi sulphides and disseminated sulphides ores, and waste [4]. Mined ore is concentrated and smelted for its $\mathrm{Cu}, \mathrm{Ni}$ and $\mathrm{Co}$ minerals [5]. The $\mathrm{Ni}-\mathrm{Cu}$ exploitation is accompanied by mine wastes which consist of various gases, particulate air matter (PAM), and tailings dump. Previous studies on the Selebi Phikwe biophysical environment revealed trends of contamination of the soils, flora and fauna [6-8]. Related studies depicted particulate air matter (PAM) and sulphur gases and fumes in the atmosphere [9]. Moreover, residents of the area generally complain of being often infected with symptoms of diseases and diseases related to respiratory tract health complications [7, 10] considered to be triggered from the on going mining activities [11]. Another study depicted the four most common human health complaints of the residents to be coughing often, frequent influenza/common colds, rampant chest pains, and frequent headaches [12, 13].

Whereas the status of chest pains and frequent coughing of the residents of Selebi Phikwe has been elucidated [13] that of influenza/common colds, and frequent headaches has not been documented in detail. In this study, the occurrence of headaches among residents of the area is investigated. According to World Health Organisation [14], headaches are symptomatic neurobiological disorders referring to a number of conditions that vary in severity, incidence and duration. Headaches could be classified as primary, secondary, or neuralgias and other headaches [15]. They could also be described in terms of types based on location and type of aches. Whereas there are different types of headaches such as those due 
to allergies, sinus headache, low blood sugar, low stomach acid, as well as cluster headaches, tension headaches, migraine, vascular and hormonal headaches, this study considered headaches in general without discriminating on clinical types. The work thus presents the findings of a survey undertaken to appraise the extent to which residents of the $\mathrm{Ni}-\mathrm{Cu}$ mining and smelting environment suffer from headaches. Attempt was made to establish the occurrence of headaches among the residents; and to postulate whether $\mathrm{Ni}-\mathrm{Cu}$ mining and smelting activities could possibly be provocative agents of the headaches.

\section{Materials and Methods}

In line with research consistency, the study area was divided into 10 sampling sites (Figure 1 and Table 1) including a chosen control site located 56 $\mathrm{km}$ from Selebi Phikwe, based on previous studies conducted there $[6-8,11-13,16]$. The control site is not in the direction of prevailing winds from Selebi Phikwe, and the residents there are not exposed to the effects of mining as those living in the other nine sites. Its biophysical environment is however similar to that of the other nine sites.
Questionnaires on status of headaches of residents of Selebi Phikwe were prepared for respondents categorised as individuals, educational institutions, business enterprises and health service providers. The different categories of respondents were randomly chosen ensuring the area of a given site was adequately covered, based on the overall population density of each site following suggestions by Czaja and Blair [17]. Details of the number of respondents for the different sets of questionnaires were as follows: 600 individuals, 7 health service providers, 200 business enterprises, and 30 educational institutions. The questionnaire reflected on regular headaches, types of headaches, and times and duration of headaches. Individuals, Headmasters of educational institutions, directors of business enterprises, health service providers and/or delegated officials responded to the questions. Statistical analyses for all the responses obtained from questionnaires were performed using the Statistical Package for Social Sciences (SPSS) [18]. Cross tabulations were undertaken to establish relationships of study sites to trends of headaches. Statistical data analysis for one sample $\mathrm{t}$ test, Pearson correlation and 95\% confidence interval were also performed.

Figure 1: Map of Selebi Phikwe showing the different study sites [12, 13]

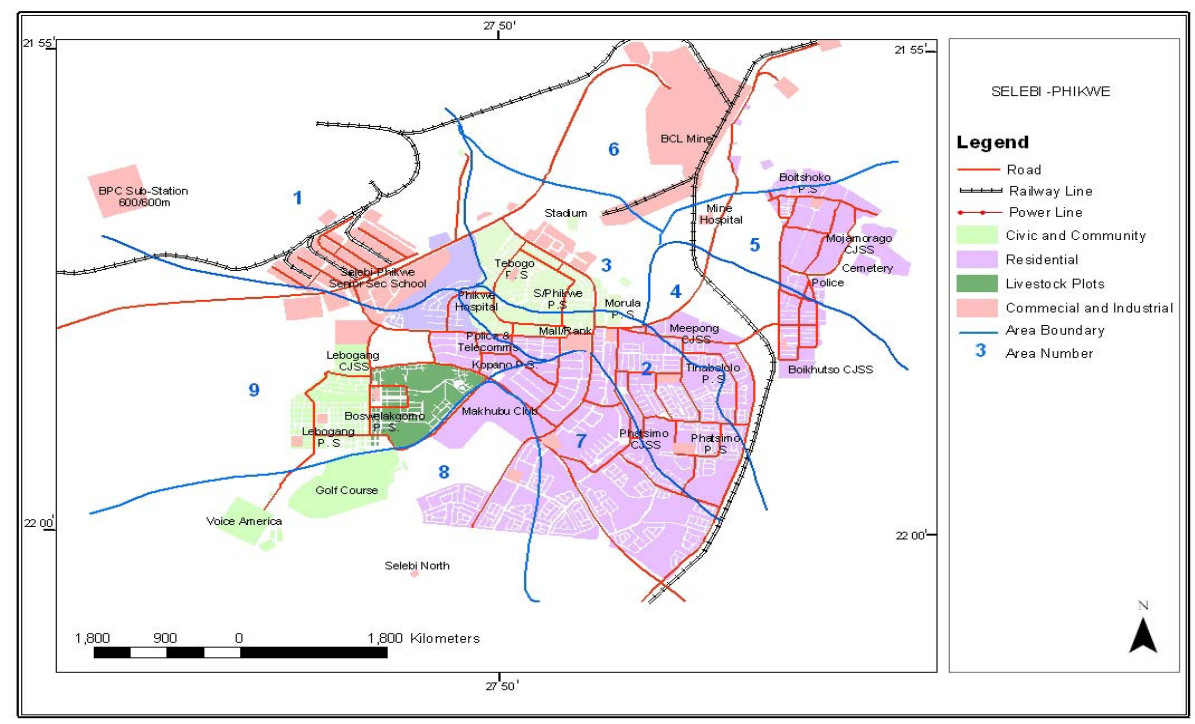

\section{Results}

Individuals

From Figure 2, it is indicative that respondents suffering from headaches were many. Except for site two where the percentage of respondents suffering from headache was as low as $39 \%$ for females and $40 \%$ for males, in all the other sites the range was from $58 \%$ of males at sites three and eight, to $98 \%$ of males at site six. Most of the respondents were not sure of the frequency of attacks of headaches. Some had it at least once a week although a fairly significant percentage indicated once a month as shown in Table 2. Some attacks were once every three months, and others once every six months. Few individuals indicated that they had headache attacks once a day, and even fewer indicated twice a week (Table 2). The test value of 2.5 , being the mean of means of the data in Table 2, was used to test whether the individual variables means differed from the test value, of which the results are plotted in Table 3 . There was 
no significant difference between the test value and the observed mean for respondents suffering from headaches once a week and once a month. However, for the $95 \%$ confidence interval, differences were observed for those suffering from headaches once a week as reflected in Table 3. A strong positive linear relationship $(\mathrm{R}=0.62)$ (Table 4) existed between the site and the frequency of respondents suffering from headaches. The results also show a positive relationship between the frequency of respondents suffering from headaches once a month and once every 3 months.

Table 1: Location and details of sites within the Selebi Phikwe study area

\begin{tabular}{|c|c|}
\hline Site & Location and details \\
\hline 1 & Industrial area (150 $\mathrm{m}$ from the railway crossing) \\
\hline 2 & Bosele Hotel (commercial area) and new township \\
\hline 3 & $\begin{array}{l}\text { Between the township stadium and the mine (behind the Botswana Power Corporation } \\
\text { (BPC)) }\end{array}$ \\
\hline 4 & $\begin{array}{l}\text { Between the township boundary and the railway line (directly behind a Community Junior } \\
\text { Secondary School (CJSS)) }\end{array}$ \\
\hline 5 & Opposite the Mine hospital, close to the old township \\
\hline 6 & Between the mine and explosives storage facilities (close to the old township) \\
\hline 7 & Towards the airport (about $250 \mathrm{~m}$ from the Airport-Sefophe-Selebi Phikwe Road juncture) \\
\hline 8 & $\begin{array}{l}\text { Off untarred road leading to the Selebi North mine (100 } \mathrm{m} \text { out of township boundary, } \\
\text { adjacent to the new township) }\end{array}$ \\
\hline 9 & Penultimate Bridge before entering the Selebi Phikwe township \\
\hline 10 & $\begin{array}{l}\text { Control site located close to the road juncture leading to Selebi Phikwe from the Gaborone- } \\
\text { Francistown main road }\end{array}$ \\
\hline
\end{tabular}

Figure 2: Distribution trend of respondents living within the Selebi Phikwe area who suffer from headaches

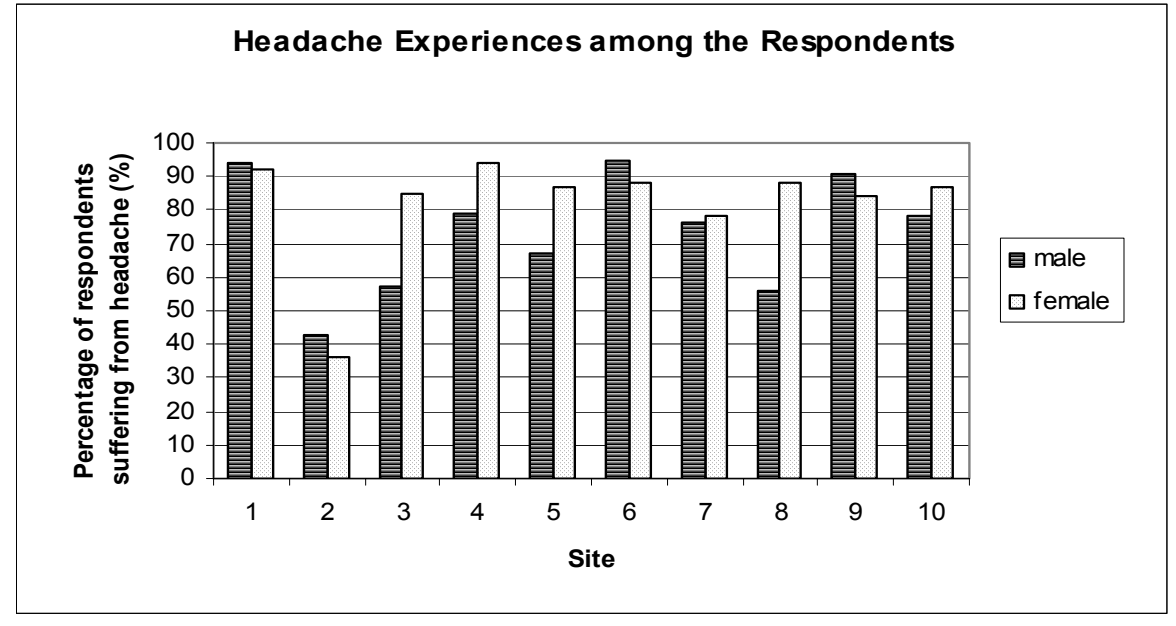

In terms of types of headaches, respondents suffered primarily from temple headaches and frontal headaches (Table 5). At site three, $4 \%$ of the females suffered from both frontal and temple headaches. A high percentage of respondents indicated that when they have headaches, the pain was felt all over the head. A test value of 3.5 being the mean of means was used to test the extent of deviation from the test value for types of headaches experienced by respondents. As shown in Table 6, there were significant differences for the respondents having headaches all over the head, on the temple at the centre of the head and at the back of the head. There were no significant differences for those respondents suffering from frontal headaches. To try to establish the relationships, the Pearson correlation coefficients were calculated and are displayed in Table 7. The results showed a positive association between frontal, back and center types of headaches indicating that respondents who suffered from frontal headaches also suffered from headaches at the centre and the back of the head. The results also showed a negative relationship between frontal headaches and the one at the temple indicating that respondents suffering from frontal headaches did not necessarily suffer from temple headaches. 
Table 2: Frequency of headaches of respondents living within the Selebi Phikwe area

\begin{tabular}{|c|c|c|c|c|c|c|c|}
\hline Site & Gender & $\begin{array}{l}\text { Once a } \\
\text { week } \\
(\%)\end{array}$ & $\begin{array}{l}\text { Once a } \\
\text { month } \\
(\%)\end{array}$ & $\begin{array}{l}\text { Once every } \\
3 \text { months } \\
(\%)\end{array}$ & $\begin{array}{l}\text { Once every } \\
6 \text { months } \\
(\%)\end{array}$ & $\begin{array}{l}\text { Not sure } \\
(\%)\end{array}$ & $\begin{array}{l}\text { Everyday } \\
(\%)\end{array}$ \\
\hline \multirow[t]{2}{*}{ One } & Male & 10 & 13 & 3 & - & 68 & - \\
\hline & Female & 25 & 4 & - & - & 63 & - \\
\hline \multirow[t]{2}{*}{ Two } & Male & 0 & 29 & - & - & 10 & 5 \\
\hline & Female & 23 & 8 & - & - & 5 & - \\
\hline \multirow[t]{2}{*}{ Three } & Male & 26 & 14 & 3 & 3 & 11 & - \\
\hline & Female & 35 & 19 & 4 & 4 & 23 & - \\
\hline \multirow[t]{2}{*}{ Four } & Male & 7 & 29 & 36 & 7 & - & - \\
\hline & Female & 19 & 56 & 16 & 3 & - & - \\
\hline \multirow[t]{2}{*}{ Five } & Male & 7 & 7 & 4 & - & 48 & - \\
\hline & Female & 27 & 13 & - & - & 43 & 3 \\
\hline \multirow[t]{2}{*}{ Six } & Male & 35 & 15 & - & 5 & 40 & - \\
\hline & Female & 25 & 10 & 5 & 5 & 43 & - \\
\hline \multirow[t]{2}{*}{ Seven } & Male & 43 & 19 & 14 & - & - & - \\
\hline & Female & 35 & 16 & - & 5 & 19 & 3 \\
\hline \multirow[t]{2}{*}{ Eight } & Male & - & - & - & - & 48 & - \\
\hline & Female & - & 3 & - & - & 85 & - \\
\hline \multirow[t]{2}{*}{ Nine } & Male & 18 & 9 & - & 5 & 59 & - \\
\hline & Female & 16 & 14 & 3 & - & 51 & - \\
\hline \multirow[t]{2}{*}{ Ten } & Male & 26 & - & - & - & 52 & - \\
\hline & Female & 30 & 10 & - & 10 & 37 & - \\
\hline
\end{tabular}

Table 3: One sample t-test of frequency of headaches of respondents living within the Selebi Phikwe area

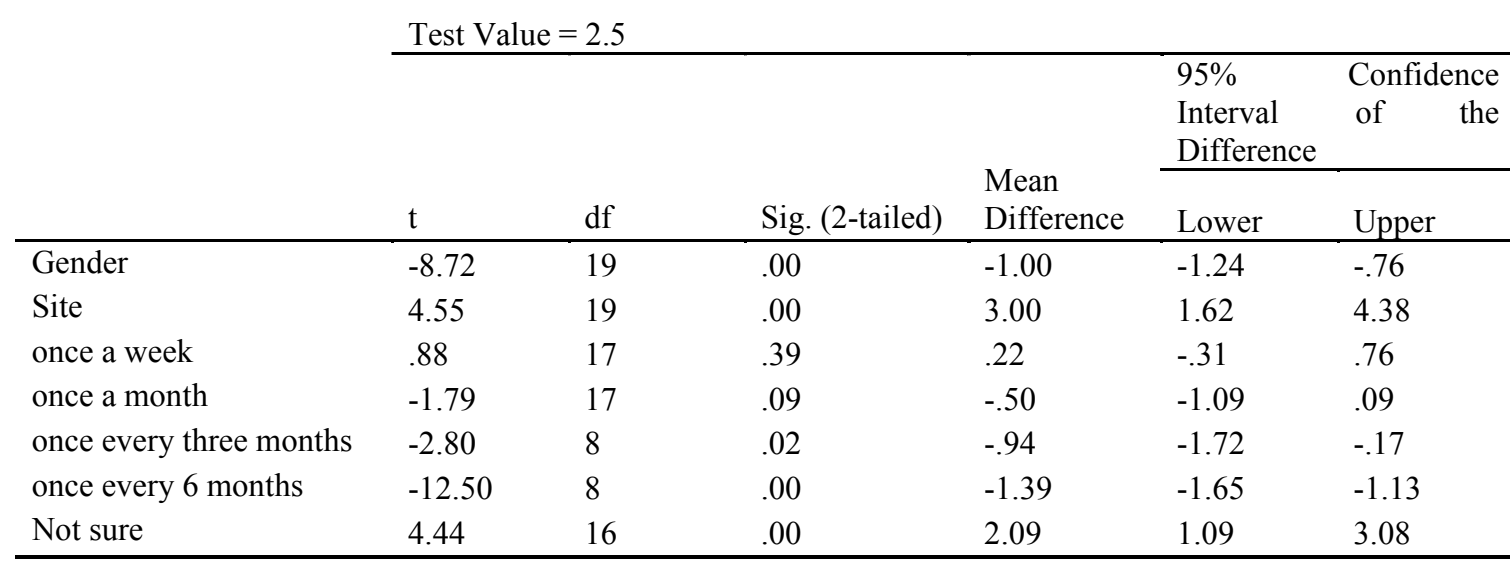

In general, slightly more females suffered from headaches than males. The most common form of headache attacks in the study area was the acute headache, followed by moderate, then dull and acute. A sizeable percentage of respondents in the control site also suffered from dull, moderate and acute headaches with the figures for females significantly higher than those for males (Table 8). The one sample t-test using 3.5 as the mean of means indicated the absence of differences between dull and acute and not sure degrees of severity of headaches. Dull, moderate and acute degrees of severity showed significant differences (Table 9). Correlation results showed a positive relationship between moderate and acute degree of severity of headaches (Table 10).

\section{Educational institutions}

The percentage distribution of learners who suffered from headaches were classified into < $20 \%, 20-30 \%, 30-40 \%, 40-50 \%$, and varied percentages. In the class of $<20 \%$, all the learners in sites three and ten, $63 \%$ in site four, $67 \%$ of those in site six and $50 \%$ of those in site nine experienced headaches. In the class of $20-30 \%$, $25 \%$ of the learners were from site four, $33 \%$ from site seven, $50 \%$ from site eight, and all of those from site five. In the class of $30-40 \%, 33 \%$ of the learners were from site seven and $50 \%$ were from site nine. In the class of $40-50 \%$, all those from site one, and $50 \%$ from site eight suffered from headaches Regarding the nature of the headaches experienced by the learners, these were dull, 
moderate, acute, and at times dull and acute. For institutions where $20-30 \%$ of learners experienced dull headaches, $25 \%$ of them were from site four, and in institutions where between $91-100 \%$ of those who complained of dull headaches, $50 \%$ were from site nine. In the class of $<20 \%$, all those in site five experienced dull, acute, and at times dull and acute headaches. Only in sites three and five did the headmasters/delegated officials indicated that learners were having moderate headaches, and in sites four and five acute headaches. A sizable percentage of learners from all the other sites except site five were not sure of the nature of headaches they experienced

Table 4: Test of significance and Pearson Correlation coefficients of frequency of headaches of respondents living within Selebi Phikwe area

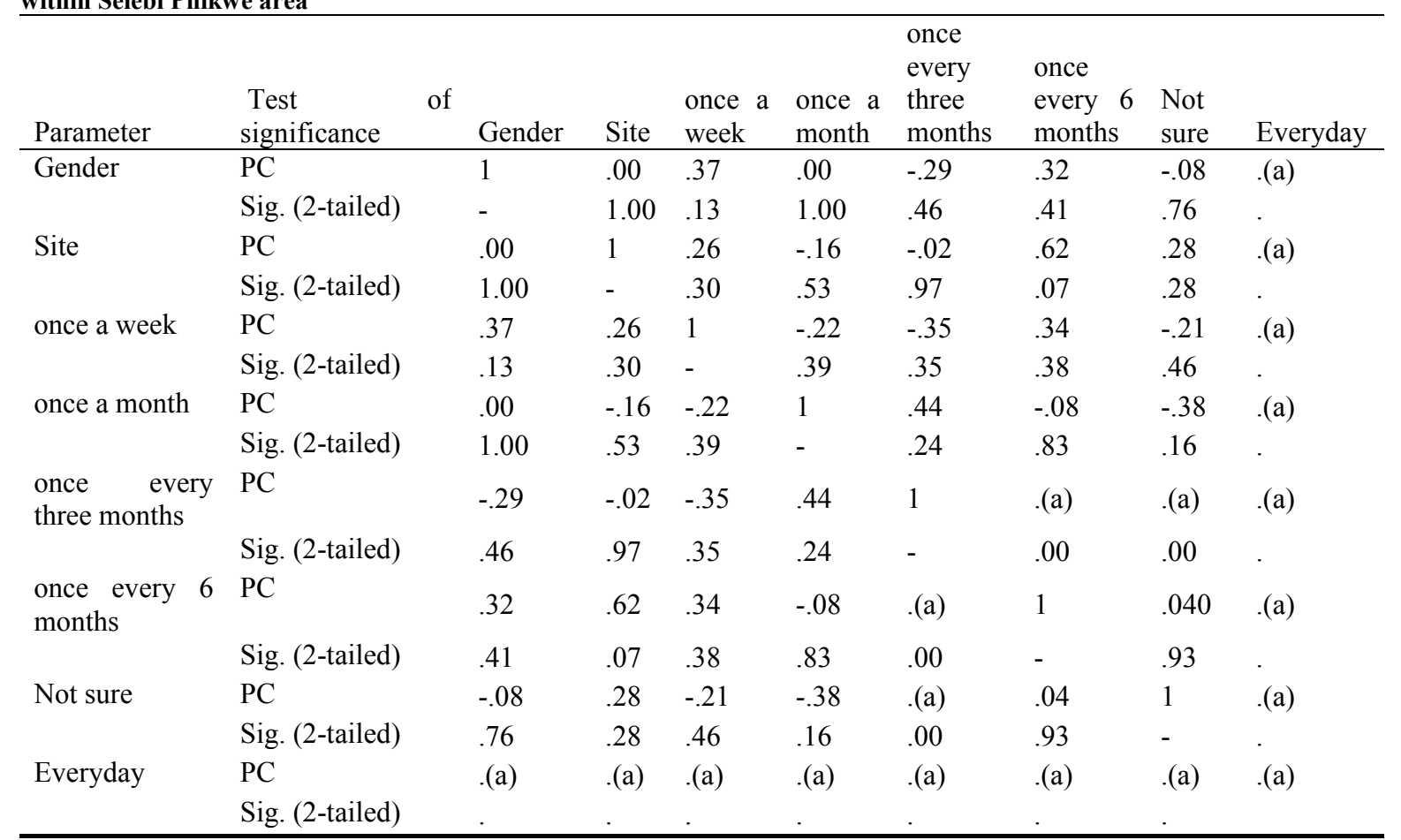

$\mathrm{a}=$ cannot be computed because at least one of the variables is constant; $\mathrm{PC}=$ Pearson Correlation

Table 5: Type of headache experienced by respondents living in the Selebi Phikwe area

\begin{tabular}{|c|c|c|c|c|c|c|}
\hline Site & Gender & Front $(\%)$ & Temple $(\%)$ & Back (\%) & Centre (\%) & All over (\%) \\
\hline \multirow[t]{2}{*}{ One } & Male & 19 & 19 & 13 & - & 42 \\
\hline & Female & 21 & 38 & - & - & 33 \\
\hline \multirow[t]{2}{*}{ Two } & Male & 14 & 19 & 5 & 5 & - \\
\hline & Female & 5 & 21 & 3 & 5 & 3 \\
\hline \multirow[t]{2}{*}{ Three } & Male & 9 & 23 & 9 & - & 17 \\
\hline & Female & 12 & 35 & 12 & 4 & 19 \\
\hline \multirow[t]{2}{*}{ Four } & Male & 7 & 25 & - & 4 & 43 \\
\hline & Female & 13 & 41 & - & - & 41 \\
\hline \multirow[t]{2}{*}{ Five } & Male & 22 & 15 & 7 & 4 & 19 \\
\hline & Female & 33 & 27 & - & 10 & 17 \\
\hline \multirow[t]{2}{*}{$\operatorname{Six}$} & Male & 25 & 30 & 10 & 25 & 5 \\
\hline & Female & 18 & 40 & 8 & 13 & 10 \\
\hline \multirow[t]{2}{*}{ Seven } & Male & 19 & 33 & 5 & - & 19 \\
\hline & Female & 30 & 16 & 3 & 8 & 22 \\
\hline \multirow[t]{2}{*}{ Eight } & Male & 15 & 26 & - & - & 15 \\
\hline & Female & 27 & 33 & - & - & 27 \\
\hline \multirow[t]{2}{*}{ Nine } & Male & 9 & 45 & 5 & 14 & 18 \\
\hline & Female & 14 & 35 & 3 & 3 & 30 \\
\hline \multirow[t]{2}{*}{ Ten } & Male & 7 & 33 & 4 & 7 & 26 \\
\hline & Female & 17 & 57 & 3 & - & 10 \\
\hline
\end{tabular}




\begin{tabular}{|c|c|c|c|c|c|c|}
\hline & \multirow[b]{2}{*}{$\mathrm{t}$} & \multirow[b]{2}{*}{$\mathrm{df}$} & \multirow[b]{2}{*}{ Sig. (2-tailed) } & \multirow{2}{*}{$\begin{array}{l}\text { Mean } \\
\text { Difference }\end{array}$} & \multicolumn{2}{|c|}{$\begin{array}{l}\text { 95\% Confidence Interval of } \\
\text { the Difference }\end{array}$} \\
\hline & & & & & Lower & Upper \\
\hline Site & 3.04 & 19 & .01 & 2.00 & .62 & 3.38 \\
\hline Gender & -17.44 & 19 & .00 & -2.00 & -2.24 & -1.76 \\
\hline Front & 1.33 & 19 & .20 & .50 & -.29 & 1.29 \\
\hline Temple & 7.24 & 19 & .00 & 3.20 & 2.28 & 4.12 \\
\hline Back & -7.98 & 13 & .00 & -1.64 & -2.09 & -1.20 \\
\hline Centre & -3.05 & 11 & .011 & -1.25 & -2.15 & -.35 \\
\hline All over & 2.80 & 18 & .01 & 1.50 & .38 & 2.62 \\
\hline
\end{tabular}

Table 7: Test of significance and Pearson Correlation coefficients of types of headaches of respondents living within Selebi Phikwe area

\begin{tabular}{|c|c|c|c|c|c|c|c|c|}
\hline & & Site & Gender & Front & Temple & Back & Centre & All over \\
\hline \multirow[t]{2}{*}{ Site } & $\mathrm{PC}$ & 1 & .00 & .05 & $.46\left(^{*}\right)$ & -.53 & .14 & -.20 \\
\hline & Sig. (2-tailed) & - & 1.00 & .82 & .04 & .05 & .66 & .42 \\
\hline \multirow[t]{2}{*}{ Gender } & $\mathrm{PC}$ & .00 & 1 & .30 & .36 & -.42 & -.18 & -.05 \\
\hline & Sig. (2-tailed) & 1.00 & - & .19 & .16 & .14 & .57 & .85 \\
\hline \multirow[t]{2}{*}{ Front } & $\mathrm{PC}$ & .05 & .30 & 1 & -.19 & .15 & .36 & -.08 \\
\hline & Sig. (2-tailed) & .82 & .192 & - & .423 & .613 & .256 & .735 \\
\hline \multirow[t]{2}{*}{ Temple } & $\mathrm{PC}$ & $.46\left(^{*}\right)$ & .36 & -.19 & 1 & -.08 & .24 & -.04 \\
\hline & Sig. (2-tailed) & .04 & .12 & .42 & - & .78 & .46 & .88 \\
\hline \multirow[t]{2}{*}{ Back } & $\mathrm{PC}$ & -.53 & -.42 & .15 & -.08 & 1 & .43 & .08 \\
\hline & Sig. (2-tailed) & .05 & .14 & .61 & .78 & - & .21 & .80 \\
\hline \multirow[t]{2}{*}{ Centre } & $\mathrm{PC}$ & .14 & -.18 & .36 & .24 & .43 & 1 & -.55 \\
\hline & Sig. (2-tailed) & .66 & .57 & .26 & .46 & .21 & - & .08 \\
\hline \multirow[t]{2}{*}{ All over } & $\mathrm{PC}$ & -.20 & -.05 & -.08 & -.04 & .08 & -.55 & 1 \\
\hline & Sig. (2-tailed) & .42 & .85 & .74 & .88 & .80 & .08 & - \\
\hline
\end{tabular}

* Correlation is significant at the 0.05 level (2-tailed).

\section{Business enterprises}

Except for sites three, six and seven, there were more workers at all the other sites than at the control site who complained of headaches. All the workers of sites five and eight, $95 \%$ of those of site one, $90 \%$ of those of site nine, $40 \%$ and $38 \%$ of those of site six suffered from headaches. Approximately $70 \%$ of the workers of the study area complained of headaches.

In terms of types of business enterprises, all the businesses had more than $50 \%$ of their workers suffering from constant headaches. Furthermore, all the mining and agricultural enterprises had workers who complained of frequent headaches, followed by $86 \%$ of the workers of liquor/bottle store; and the lowest being $64 \%$ of the workers of the hotel/food industry. Of the workers complaining of headaches, the business enterprises reported that there were varied percentages of the type of aches which were dull, moderate, acute, and at times dull and acute.

\section{Health service providers}

There were only seven health service providers in the study area and according to study sites, health services were not located in sites one, three and seven. All the health service providers however indicated that they had patients who complained of frequent headaches. Whereas $29 \%$ of the health service providers indicated that $<20 \%$ of their patients complained of headaches, $71 \%$ of the service providers had varied percentages of patients with the complaint. Of the patients complaining of headaches, the health service providers reported that the different types of the aches were dull, moderate, acute, and at times dull and acute and in varied percentages. 
Table 8: Degree of severity of headaches experienced by respondents within the study area

\begin{tabular}{|c|c|c|c|c|c|c|}
\hline Site & Gender & $\begin{array}{l}\text { Dull } \\
(\%)\end{array}$ & $\begin{array}{l}\text { Moderate } \\
(\%)\end{array}$ & Acute $(\%)$ & $\begin{array}{l}\text { Dull and } \\
\text { Acute }(\%)\end{array}$ & $\begin{array}{l}\text { Not sure } \\
(\%)\end{array}$ \\
\hline \multirow[t]{2}{*}{ One } & Male & 3 & 26 & 23 & 29 & 13 \\
\hline & Female & - & 21 & 33 & 33 & 4 \\
\hline \multirow[t]{2}{*}{ Two } & Male & 14 & 14 & 5 & 10 & - \\
\hline & Female & 5 & 15 & 5 & 8 & 3 \\
\hline \multirow[t]{2}{*}{ Three } & Male & 3 & 3 & 26 & 9 & 17 \\
\hline & Female & 4 & 23 & 19 & 19 & 19 \\
\hline \multirow[t]{2}{*}{ Four } & Male & 7 & 14 & 4 & 50 & 4 \\
\hline & Female & 6 & 22 & 34 & 31 & - \\
\hline \multirow[t]{2}{*}{ Five } & Male & - & 15 & 22 & 7 & 22 \\
\hline & Female & 10 & 20 & 27 & 7 & 23 \\
\hline \multirow[t]{2}{*}{ Six } & Male & - & 40 & 40 & 15 & - \\
\hline & Female & 8 & 35 & 33 & 5 & 8 \\
\hline \multirow[t]{2}{*}{ Seven } & Male & 5 & 38 & 33 & - & - \\
\hline & Female & - & 43 & 22 & 14 & - \\
\hline \multirow[t]{2}{*}{ Eight } & Male & - & 11 & 37 & 4 & 4 \\
\hline & Female & 6 & 33 & 42 & 6 & - \\
\hline \multirow[t]{2}{*}{ Nine } & Male & - & 23 & 41 & 9 & 18 \\
\hline & Female & 3 & 14 & 41 & 11 & 16 \\
\hline \multirow[t]{2}{*}{ Ten } & Male & 7 & 15 & 15 & 11 & 30 \\
\hline & Female & 10 & 33 & 33 & 3 & 7 \\
\hline
\end{tabular}

Table 9: One sample t-test of degree of severity of headaches of respondents living within the Selebi Phikwe area

\begin{tabular}{|c|c|c|c|c|c|c|}
\hline & \multicolumn{6}{|c|}{ Test Value $=3.5$} \\
\hline & \multirow[b]{2}{*}{$\mathrm{t}$} & \multirow[b]{2}{*}{ df } & \multirow[b]{2}{*}{ Sig. (2-tailed) } & \multirow{2}{*}{$\begin{array}{l}\text { Mean } \\
\text { Difference }\end{array}$} & \multicolumn{2}{|c|}{$\begin{array}{l}95 \% \text { Confidence Interval } \\
\text { of the Difference }\end{array}$} \\
\hline & & & & & Lower & Upper \\
\hline Site & 3.04 & 19 & .01 & 2.00 & .62 & 3.38 \\
\hline Gender & -17.44 & 19 & .00 & -2.00 & -2.24 & -1.76 \\
\hline Dull & -8.06 & 13 & .00 & -1.57 & -1.99 & -1.15 \\
\hline Moderate & 3.33 & 19 & .00 & 1.70 & .63 & 2.77 \\
\hline Acute & 4.01 & 19 & .001 & 2.25 & 1.08 & 3.42 \\
\hline Dull and acute & -.14 & 18 & .89 & -.08 & -1.24 & 1.08 \\
\hline Not sure & -.71 & 13 & .49 & -.36 & -1.44 & .73 \\
\hline
\end{tabular}

\section{Discussion}

The average values obtained for headaches were as follows: health service providers $(100 \%)$, educational institutions $(80 \%)$, individuals $(77 \%)$ and business enterprises $(70 \%)$. The values for sites four, five, six and nine for individuals, educational institutions, health service providers, and enterprises were significantly very high. Values for complaints of headaches for the control site were also high. For individuals complaining of frequent headaches, figures for sites one, four, six and nine were more than those for the control site. For the educational institutions, percentages of learners suffering from headaches in all the sites were more than that for the control site except site two which was only $20 \%$. All the health service providers in all the sites had patients who complained of headaches. Concerning business enterprises, except sites three, six and seven, the percentages of workers who complained of headaches were above that of the control site. In general, percentages for headaches at all sites were significantly high with higher values for sites closer to the mine and smelter/concentrator plant. The high occurrences of headaches at Selebi Phikwe could be affecting the student and working populations. Students suffering headaches lack concentrations, and often stay away from school during periods of attacks. Similarly, productivity of workers is reduced [19]. 
Table 10: Test of significance and Pearson Correlation coefficients of types of headaches of respondents living within Selebi Phikwe area

\begin{tabular}{|c|c|c|c|c|c|c|c|c|}
\hline & & Site & Gender & Dull & Moderate & Acute & $\begin{array}{l}\text { Dull and } \\
\text { acute }\end{array}$ & Not sure \\
\hline \multirow[t]{2}{*}{ Site } & $\mathrm{PC}$ & 1 & .000 & .215 & .266 & .373 & $-.516(*)$ & .340 \\
\hline & Sig. (2-tailed) & - & 1.000 & .459 & .257 & .105 & .024 & .234 \\
\hline \multirow[t]{2}{*}{ Gender } & $\mathrm{PC}$ & .000 & 1 & .117 & .269 & .061 & -.054 & -.237 \\
\hline & Sig. (2-tailed) & 1.000 & - & .690 & .251 & .797 & .825 & .414 \\
\hline \multirow[t]{2}{*}{ Dull } & $\mathrm{PC}$ & .215 & .117 & 1 & .188 & -.322 & -.230 & -.104 \\
\hline & Sig. (2-tailed) & .459 & 690 & - & .519 & .261 & .449 & .774 \\
\hline \multirow[t]{2}{*}{ Moderate } & $\mathrm{PC}$ & .266 & .269 & .188 & 1 & .294 & -.056 & -.181 \\
\hline & Sig. (2-tailed) & .257 & .251 & .519 & - & .209 & .821 & .537 \\
\hline \multirow[t]{2}{*}{ Acute } & $\mathrm{PC}$ & .373 & .061 & -.322 & .294 & 1 & -.220 & .152 \\
\hline & Sig. (2-tailed) & .105 & .797 & .261 & .209 & - & .365 & .605 \\
\hline \multirow[t]{2}{*}{$\begin{array}{l}\text { Dull and } \\
\text { acute }\end{array}$} & $\mathrm{PC}$ & $\begin{array}{l}- \\
.516(*\end{array}$ & -.054 & -.230 & -.056 & -.220 & 1 & -.354 \\
\hline & Sig. (2-tailed) & .024 & .825 & .449 & .821 & .365 & - & .214 \\
\hline \multirow[t]{2}{*}{ Not sure } & $\mathrm{PC}$ & .340 & -.237 & -.104 & -.181 & .152 & -.354 & 1 \\
\hline & Sig. (2-tailed) & .234 & .414 & .774 & .537 & .605 & .214 & - \\
\hline
\end{tabular}

* Correlation is significant at the 0.05 level (2-tailed).

There are several types of headaches, as well as different causes of headaches [20,21]. The high incidence of headache in the control site could be indicative of other causes apart from air pollution which may be responsible for headaches suffered by residents of the study area. Other factors suspected to be responsible for headaches at the study area are caffeine and alcohol consumption as depicted in a related study [22]. There are several other environmental factors such as the climate, tobacco smoke which can cause nasal congestion thereby triggering headaches. A recent broadcast on Voice of America (VOA) [20] indicated that females generally suffer more from headaches than males. Headaches of females could also be associated with hormonal and monthly physiological changes as well as menopause [23], unlike for male, whose headaches are usually stress-related.

The mining and processing of sulphide minerals at Selebi Phikwe is accompanied by mine waste. These wastes lead to the formation of different gas and PAM contents, deposition of tailings dump, and contamination of surrounding soils, vegetation and animals. It was demonstrated in a previous study carried out by Ekosse [16], how the physico-chemical processes at Selebi Phikwe affect the immediate environmental constituents. Inhalation of fumes and PAM containing heavy metals such as Ni may cause headaches [24]. Fumes rich in sulphur, nitrous oxides $\left(\mathrm{NO}_{\mathrm{x}}\right)$ and other associated gases are deleterious to human life [25]. The fumes cause headaches, anxiety, choking and shortness of breath [26], which culminates to severe breathing problems and permanent damage to lungs [27]. In Australia, the health effects resulting from $\mathrm{Ni}$ smelting has been documented [26]. The emissions of $\mathrm{SO}_{2}, \mathrm{CO}, \mathrm{CO}_{2}$, and other gases from concentrator and smelter plants affect people. Hot climate and regular exposure to sunlight are triggering factors of headaches [28], and these are prevalent at Selebi Phikwe. Frequent and persistent headaches have been diagnosed as precursors of meningitis, malaria and stroke. At Selebi Phikwe residents complained of these symptoms, and deaths were reported as a result of meningitis, malaria, cardiac arrest, diabetes and stroke. While there may be several causes of these diseases, at Selebi Phikwe PAM and gaseous fumes from mining activities, as well as high temperatures and sunlight exposure could possibly be contributory to the prevailing headaches.

\section{Conclusion}

This study was initiated based on general complaints from residents of the study area that they often have headaches which could be related to mining activities [7]. Questionnaires were administered to individuals, educational institutions, business enterprises and health service providers. Results indicated very high prevalence of headaches among the different sampled populations. More than $70 \%$ each of the following sampled population: health service providers, educational institutions, individuals and business enterprises suffered from headaches. Frontal, back and central headaches were the dominant types of headaches suffered by individuals at Selebi Phikwe. Although more individuals suffered from headaches at least once a week, there was however 
a positive correlation between those who suffered from headaches once a month and those who suffered from it once every three months. Furthermore moderate and acute headaches were the degrees of severity of headaches commonly suffered by the individuals.

The findings of this study are supported by those obtained for related study at Selebi Phikwe [6 $-8]$. The findings tend to substantiate suggestions of residents who are of the opinion that the rampant headaches are provoked by the mining and smelting activities; the main factors being dust, fumes, gases and noise. These factors emanating from mining and smelting activities could have a direct bearing on the health of the residents of the area [12]. Further work is called for to substantiate the findings of this baseline study on the prevalence of headaches at the Selebi Phikwe Ni$\mathrm{Cu}$ mine area, Botswana.

\section{References}

1. Botswana Government National Census. National population and housing census report 1991. Government Printer, Gaborone, Botswana.

2. Department of Town and Regional Planning Selebi Phikwe Development Plan: 1996 2016. Selebi Phikwe Town Council, Botswana. 1996; p 55.

3. BCL. The Bamangwato Concessions Limited Environmental Control Report. 1997; pp 60

4. Gallon ML. Structural re-interpretation of the Selebi Phikwe nickel-copper sulphide deposits, Eastern Botswana. In Anhaeusser C.R. and Maske S (Eds) Mineral deposits of southern Africa. Geology Society of South Africa. 1986; 1\&2: 1663-1669

5. Nkoma JS, Ekosse G. X-ray diffraction study of chalcopyrite $\mathrm{CuFeS}_{2}$, pentlandite $(\mathrm{Fe}, \mathrm{Ni})_{9} \mathrm{~S}_{8}$ and pyrrhotite $\mathrm{Fe}_{1-\mathrm{x}} \mathrm{S}$ obtained from $\mathrm{Cu}-\mathrm{Ni}$ ore bodies. Journal of Physics: Condensed Matter. 1999; 11: 121-128

6. Ekosse G, Chaoka R, Alemaw BF, van den Heever DJ, de Jager L Distribution of heavy metals concentrations around the Selebi Phikwe $\mathrm{Ni}-\mathrm{Cu}$ mine area, south eastern Botswana. In Ngowi AB, Feldman C, Matshediso B, Mathiba J, and Segawa S (Editors) Proceedings of the $1^{\text {st }}$ Botswana International Conference on Mining. Challenges facing the minerals industry in developing countries. 20-22 November, 2002, 157-166

7. Ekosse G, Van den Heever DJ, De Jager L, Totolo O. Environmental mineralogy of soils around Selebi Phikwe nickel-copper plant, Botswana. International Journal of Environmental Studies. 2003; 60: 251-262
8. Ekosse G, Van den Heever DJ, De Jager L, Totolo O. Mineralogy of tailings dump around Selebi Phikwe nickel-copper plant, Botswana. Journal of Applied Sciences \& Environmental Management. 2004; 8: 37-44.

9. Ekosse G, Van den Heever DJ, De Jager L, Totolo O. Environmental chemistry and mineralogy of particulate air matter around Selebi Phikwe nickel-copper plant, Botswana. International Journal of Minerals Engineering .2004a; 17: 349-353

10. Asare B. Perceptions on socio-economic and environmental impacts of mining in Botswana: A case study of the Selebi Phikwe Cu-Ni mine. Unpublished MSc thesis, University of Botswana, Gaborone, Botswana, 1999; p126

11. Ekosse G, de Jager L, van den Heever D, Totolo O. Heavy metals concentrations in Imbrasia belina (phane caterpillar) around the Selebi Phikwe Ni-Cu mine and smelter/concentrator plant, Botswana. Global Journal of Pure and Applied Sciences. 2005; 11: 553 - 559

12. Ekosse G General health status of residents of the Selebi Phikwe Ni-Cu mine area, Botswana. International Journal of Environmental Health Research. 2005; 15: $373-381$

13. Ekosse G, de Jager L, van den Heever D (2005a) The occurrences of chest pains and frequent coughing among residents living within the Selebi Phikwe $\mathrm{Ni}-\mathrm{Cu}$ Mine area, Botswana. 2005a; African Journal of Health Sciences. 12: 37-48

14. World Health Organisation. Headache disorders and Public Health, Education and Management Implications. World Health Organisation, Geneva, WHO/MSD/MBD/00.9, September 2000

15. World Health Organisation. Headache disorders. World Health Organisation fact sheet No. 277, March 2004

16. Ekosse G. Heavy metals concentrations in the biophysical environment around the $\mathrm{Ni}-\mathrm{Cu}$ mine and smelter/concentrator plant, Selebi Phikwe, Botswana. Global Journal of Environmental Science. 2005a; 4: 97 - 110

17. Czaja R, Blair J. Designing surveys. A guide to decisions and procedures. Newbury Park, California, USA, Pine Forge Press, 2003; p 269

18. Statistical package for Social Sciences Version (2003) Statistical package for Social Sciences, SPSS Version 11.2. Chicago, Illinois, USA: SPSS Inc.

19. Vadikolias K, Heliopoulos I, Tripsianis G, Achtaropoulos A, Homsioglou E, Artemis N, Piperidou H, Milonas I. Headache-related work disability in young men. The 2002. Journal of Headache and Pain; 3: 87-91 
20. Voice of America. Night line Africa. The Home Doctor. Radio Program broadcast on AM 909, 5 September 2003

21. Inflam-Med. Hypoglycemia, hyperglycemia, high and low blood sugar. http://www.gouttreatment.com/blood sugar h ypoglycemia.html. (23 August 2003)

22. Ekosse G, Van den Heever D, De Jager L Social, recreational and housing habits of residents living within the Selebi Phikwe Ni$\mathrm{Cu}$ Mine area, Botswana. African Journal of Physical Health Education Recreation and Dance. 2006. (in press)

23. Karakurum B, Naldöken S, Ortapamuk H, Üčler S. Menstrual migraine and SPECT. 2002. The Journal of Headache and Pain; 3 : 143-147

24. Trace Elements Laboratories (Clinical interpretations. Erythrocyte (red blood cell) elements 2004). London Laboratories Services Group. (12 January 2005)

http://www.lhsc.on.ca/lab/metals/clinical.htm

25. Prospero J.M Long-range transport of mineral dust in the global atmosphere: Impact of African dust on the environment of the southeastern United States of America. Colloquium paper presented at the National Academy of Sciences on Geology, Mineralogy, and Human Welfare, Held Nov 89, 1998, Arnold and Mabel Beckman Centre, Irvine, CA, USA. 96: 3396-3403. 1999

26. Nichols B. (2001) Workers condemn company over sulphur fumes at West Australian mine. Published by the International Committee of the Fourth International. http://www.wsws.org/articles/2001/jun2001/mi ne-j27.shtml. (12 January 2005)

27. Environmental Health Center Air Pollution Fact Sheet (for New Drivers). http://www.nsc.org/ehc/mobile/airpollu.htm. (12 January 2005)

28. Haimanot R. T. Burden of headache in Africa. The Journal of Headache and Pain; 20034 : s47-s54 